\title{
Effect of bokashi improved with rock phosphate on parsley cultivation under organic greenhouse management
}

\author{
Vicente Maass ${ }^{1}$, Cecilia Céspedes ${ }^{2 *}$, and Claudio Cárdenas ${ }^{3}$ \\ ${ }^{1}$ Universidad Mayor, Facultad de Ciencias Silvoagropecuarias, Camino La Pirámide 5750, Santiago, Chile. \\ ${ }^{2}$ Instituto de Investigaciones Agropecuarias, INIA Quilamapu, Av. Vicente Méndez 515, Chillán, Chile. \\ *Corresponding author (cecilia.cespedes@inia.cl). \\ ${ }^{3}$ Servicio Agrícola y Ganadero (SAG), Paseo Bulnes 241 piso 7, Santiago, Chile.
}

Received: 9 March 2020; Accepted: 11 May 2020; doi:10.4067/S0718-58392020000300444

\begin{abstract}
The application of stabilized organic matter to the soil is essential for the sustainability of a production system. Bokashi is a biofertilizer produced by the aerobic decomposition of organic matter that contributes to the conservation of soil fertility. The objective of this study was to evaluate the effect of bokashi improved with rock phosphate on a curled parsley crop (Petroselinum crispum [Mill.] Fuss var. crispum) under organic management. The process to prepare bokashi at 9\% rock phosphate (BP) and without rock phosphate (BK) was evaluated in all treatments at the same temperature, $\mathrm{pH}$, electrical conductivity, and moisture content. Afterward, the effect of applying bokashi on potted curled parsley was evaluated for 10 treatments and 5 replicates. Treatments consisted of three rates $(10 \%, 15 \%$, and 30\%) of three P fertilization sources: bokashi with rock phosphate added to the process (BRE), bokashi without rock phosphate (BSR), bokashi without rock phosphate in the process plus rock phosphate added to the pot (BRM), and a control without bokashi (B0). The chlorophyll index, dry matter (DM), foliar P content, and soil available $\mathrm{P}$ were evaluated after harvest. The addition of rock phosphate to the compost increased soluble P content by $17.7 \%$ and nearly doubled soluble Ca. The BRM treatment at $30 \%$ obtained the highest chlorophyll index and BRE at 15\% had the maximum DM value. Treatments with bokashi at $30 \%$ obtained the highest foliar P content and soil available P. All treatments, except BSR at 10\%, improved the chlorophyll index and DM. The evaluated parameters did not vary according to the type of bokashi, but responded to different rates.
\end{abstract}

Key words: Bokashi, organic fertilizer, rock phosphate.

\section{INTRODUCTION}

Phosphorus $(\mathrm{P})$ is one of the most important chemical elements for plant growth and development. However, its availability is limited in most natural ecosystems (Delfim et al., 2018). The largest portion of $\mathrm{P}$ applied to the soil as fertilizer is not efficiently used by plants due to the intense retention processes that occur in the soil (Roy et al., 2016); this creates the need to find more efficient alternative sources of $\mathrm{P}$, such as the formulation of organic-mineral fertilizers by composting organic waste mixed with soluble fertilizers or rock phosphate (Maluf et al., 2018).

The use of biofertilizers or organic fertilizers can be crucial for a sustainable agricultural system, increasing soil productivity by improving its physical, chemical, and biological characteristics (Patel et al., 2015). The incorporation of organic matter (OM) to the soil has a positive effect on characteristics such as aggregation, water infiltration, water retention capacity, cation exchange capacity, nutrient availability, and increased soil microbial biomass (Karazija et al., 2015). The addition of OM is usually obtained through compost. However, composting presents challenges for farmers, such as the need for infrastructure and specialized equipment and the different parameters to comply with quality standards (Christel, 2017). 
There are alternatives to compost that have been less explored in agricultural systems. One of these is bokashi, which is the decomposition of OM with the inoculum of microbes using different formulae (Christel, 2017). It is considered as an organic fertilizer that can be used to nourish crops, increase plant growth and production, and improve soil structure and soil water retention (Karimuna et al., 2016; Zaman et al., 2016).

Diverse studies have found that the use of bokashi has positive effects on soil fertility and crop production (Dou et al., 2012). Ferreira et al. (2016) observed that applying bokashi improved the vegetative growth of lettuce and nematode control. Christel (2017) reported that bokashi increased the height and biomass of spinach under greenhouse conditions.

The objective of this research study was to evaluate the effect of bokashi improved with rock phosphate on a curled parsley crop under organic greenhouse management.

\section{MATERIALS AND METHODS}

To prepare and sample the biofertilizer and measure its effect on parsley (Petroselinum crispum [Mill.] Fuss var. crispum), trials were set up in an organic plot at the Santa Rosa Experimental Station of the Instituto de Investigaciones Agropecuarias, INIA Quilamapu (36³2.29' S, 7155.36 W; 192 m. a.s.1.), Chillán, Nuble Region, Chile, and measurements were completed in the Agroecological laboratory. The study was divided into two assays; the first was to prepare the bokashi and the second to evaluate parsley plants.

Samples from the top $20 \mathrm{~cm}$ of soil (silt loam Inceptisol Andic Xerochrepts) were collected and analyzed, with values of $160 \mathrm{mg} \mathrm{N} \mathrm{kg}^{-1}, 5.46 \mathrm{mg} \mathrm{P} \mathrm{kg}^{-1}, 127.8 \mathrm{mg} \mathrm{K} \mathrm{kg}^{-1}, \mathrm{pH} 5.55,0.27 \mathrm{dS} \mathrm{m}^{-1}$ electrical conductivity (EC), and 10.28\% organic matter $(\mathrm{OM})$.

\section{Preparation of bokashi with added rock phosphate}

Bokashi was placed in piles under a shed with a completely randomized experimental design and three replicates. Rock phosphate at 9\% (Cerrifos, Ecofos, Santiago, Chile) was added to some bokashi piles to produce improved bokashi and other piles were without rock phosphate.

All the raw materials were weighed. Six pieces $(2 \times 2 \mathrm{~m})$ of plastic sheeting were placed under a shed to avoid contamination with the ground and prevent moisture loss during the preparation. A volcano-shaped pile of $40 \mathrm{~kg}$ soil was placed on each piece of plastic and $30 \mathrm{~kg}$ wheat middlings and $40 \mathrm{~kg}$ fresh cow manure were added in the center. To three piles, $10 \mathrm{~kg}$ rock phosphate was added to obtain $9 \%$ rock phosphate in relation to the total mass. Meanwhile, $1 \mathrm{~L}$ yogurt, $20 \mathrm{~g}$ yeast, and $20 \mathrm{~g}$ molasses diluted in $5 \mathrm{~L}$ water were mixed and incorporated into each pile. Water was added to the mixture until each pile contained $25 \mathrm{~L}$. Piles were homogenized by successive turns until they were approximately $30 \mathrm{~cm}$ high. Finally, they were covered with pieces of plastic of the same size as the base to impede moisture and temperature loss and keep insects and other animals from entering.

For the following $3 \mathrm{~d}$, each pile of bokashi was mixed three times a day and covered again, followed by $3 \mathrm{~d}$ of mixing twice a day and left uncovered. Before mixing the piles, the temperature was measured (two replicates) at 10:00 h; after a sample was mixed, moisture, $\mathrm{pH}$, and EC were determined for each pile of bokashi. On days 2 and 3, piles were kept 30 $\mathrm{cm}$ high and covered with plastic, and on day 4 they were reduced to $15 \mathrm{~cm}$ high and uncovered until day 7 when the pile was reduced again to $10 \mathrm{~cm}$ to lose moisture until day 8 .

\section{Evaluation of the finished bokashi}

The preparation process and final quality of bokashi with (BP) and without rock phosphate (BK) was evaluated. Temperature, $\mathrm{pH}, \mathrm{EC}$, and moisture were measured throughout the oxidation process.

On day 8, after the oxidation process of bokashi ended, samples from each pile were taken to perform a chemical analysis and determine $\mathrm{OM}$, total $\mathrm{C}$, soluble Olsen $\mathrm{P}, \mathrm{EC}, \mathrm{pH}$, and ammoniacal and nitric $\mathrm{N}, \mathrm{Ca}$, and $\mathrm{K}$ according to the methods described by Sadzawka et al. (2006). These values were compared with accepted values for compost based on the 2015 Chilean Norm 2880 (INN, 2015). 


\section{Establishment of parsley bioassay}

Bokashi and soil were mixed in a wheelbarrow to prepare the different substrates and fill the pots according to the 10 established treatments (Table 1). Each treatment had five replicates for a total of 50 experimental units.

The methodology used for substrate preparation, sowing, harvesting, measuring, and statistical analysis was an adaptation of the method described by Schenkel and Baherle (1971) to study soil fertility through intensive potting experiments.

The bottom of the pot was covered to avoid substrate loss through the drainage holes. Pots were filled with substrate, tapped five times to correct irregularities and leave a space of $3 \mathrm{~cm}$ from the top. Finally, the substrate was soaked to field capacity before sowing.

The assay was carried out on 2 March 2015 in $1.2 \mathrm{~L}$ pots that were filled with substrate as indicated in Table 1 . Seeds $(1.25 \mathrm{~g})$ were spread homogenously over the substrate and covered with $50 \mathrm{~cm}^{3}$ of fine sifted soil in each pot. Pots were placed on a counter in the greenhouse using a completely randomized experimental design. They were watered with 50 $\mathrm{mL}$ potable water with a hand sprayer. Watering was repeated twice a day during the germination stage. Once parsley plantlets appeared, each pot was watered with $100 \mathrm{~mL}$ once a day; pots were watered with a sprinkler hose after $40 \mathrm{~d}$. Harvest was $142 \mathrm{~d}$ after sowing.

\section{Evaluation of plant material and remaining pot soil}

Once the plants reached a $15 \mathrm{~cm}$ height from the top edge of the pots, leaf chlorophyll index was measured with a SPAD 502 chlorophyll meter (Konica Minolta, Tokyo, Japan) by introducing leaves into the caliper and taking five measurements per pot. Afterward, plants were cut with scissors from each experimental unit at the top edge of the pot and the plant material was stored in previously labeled paper bags. Samples were dried at $65{ }^{\circ} \mathrm{C}$ for $48 \mathrm{~h}$ and weighed to determine DM. Subsequently, the plant material was ground and packed in small paper bags. Foliar P content was determined by calcination and colorimetry of the phosphovanadomolybdate complex.

At the end of the assay, the substrate was recovered, sifted, and the Olsen P content determined by colorimetry with molybdenum blue. Both methods of P have been described by Sadzawka et al. (2006).

\section{Statistical analysis}

The assays had a completely randomized experimental design. To determine statistical differences in the bokashi preparation process and evaluation assays, collected data were subjected to an ANOVA and separation of means by the Student-Fischer t-test. For plant and soil parameter evaluations, collected data were subjected to ANOVA and separation of means by Tukey's test $(\mathrm{P} \leq 0.05)$. The statistical analysis was performed with the InfoStat 2015 statistical software (Grupo InfoStat, Facultad de Ciencias Agropecuarias, Universidad Nacional de Córdoba, Córdoba, Argentina).

Table 1. Treatments of the parsley bioassay.

\begin{tabular}{lccl}
\hline Treatment & Soil content & Bokashi rate & Type of bokashi \\
\hline & $\%$ & $\%$ & \\
B0 (Control) & 100 & 0 & Without bokashi and without rock phosphate \\
BRE10 & 90 & 10 & Bokashi with 9\% rock phosphate in the composting process \\
BSR10 & 90 & 10 & Bokashi without rock phosphate \\
BRM10 & 90 & 10 & Bokashi without rock phosphate $+9 \%$ rock phosphate in the pot \\
BRE15 & 85 & 15 & Bokashi with $9 \%$ rock phosphate in the composting process \\
BSR15 & 85 & 15 & Bokashi without rock phosphate \\
BRM15 & 85 & 15 & Bokashi without rock phosphate $+9 \%$ rock phosphate in the pot \\
BRE30 & 70 & 30 & Bokashi with $9 \%$ rock phosphate in the composting process \\
BSR30 & 70 & 30 & Bokashi without rock phosphate \\
BRM30 & 70 & 30 & Bokashi without rock phosphate $+9 \%$ rock phosphate in the pot \\
\hline
\end{tabular}




\section{RESULTS AND DISCUSSION}

\section{Physicochemical properties of bokashi during the oxidation process}

The $\mathrm{pH}$ behavior was similar in both the BP and BK treatments; on day 1 of the mixture preparation $\mathrm{pH}$ began to decrease due to biodegradation and the constant production of organic acids (Zaha et al., 2013) but tended to stabilize at values of 7.9, which is close to neutral pH (Figure 1A). This value is similar to findings reported by Saldaña et al. (2014).

The temperature of each pile increased as microbial activity increased, rapidly reaching a thermophilic phase (Sharma et al., 2017) after which it sharply declined due to the required decrease in the height of the piles on day 7 (Figure 1B).

The EC of the treatments decreased during the biofertilizer preparation and at the end of the process had values close to $4.8 \mathrm{dS} \mathrm{m}^{-1}$ (Figure 1C), similar to those reported by Boudet et al. (2015). These EC values can be attributed to the high content of ammonium and mineral salts produced by the degradation of OM that releases ammonium and phosphates (Sharma et al., 2017). The decrease in EC can be attributed to ammonia volatilization and mineral salt precipitation over time (Chennaoui et al., 2018).

Initial moisture decreased as the substrate was transformed, and by increasing the temperature and turning the piles (Figure 1D), water was released as steam. The BP exhibited the lowest amount of water during the whole preparation process. This is due to the dilution effect because the same amount of water was used for both types of bokashi; however, the rock phosphate treatment had a larger total volume and mass.

\section{Physicochemical properties of the finished bokashi}

Bokashi quality was determined using compost quality parameters because the parameters for bokashi have not yet been developed; both are the product of biological oxidation of a mixture of plant and animal material in the presence of temperature and moisture ( $\mathrm{SAG}, 2013$ ). The content of $\mathrm{OM}, \mathrm{pH}$, total $\mathrm{N}$, and $\mathrm{C} / \mathrm{N}$ ratio of the piles were within the normal range for compost (NCh 2880; INN, 2015); however, it was mostly in its nitric form (Table 2). Both bokashi treatments have very high levels of ammoniacal $\mathrm{N}$, which is associated with the conversion of organic $\mathrm{N}$ into ammoniacal $\mathrm{N}$ by the ammonification process during the first days of decomposition (Kalamdhad and Kazmi, 2009; Wang et al., 2013). In the

Figure 1. Evolution of physicochemical parameters in the composting process, with and without the addition of rock phosphate. Evolution of $\mathrm{pH}(\mathrm{A})$, temperature (B), electrical conductivity (C), and moisture (D) during the composting process.
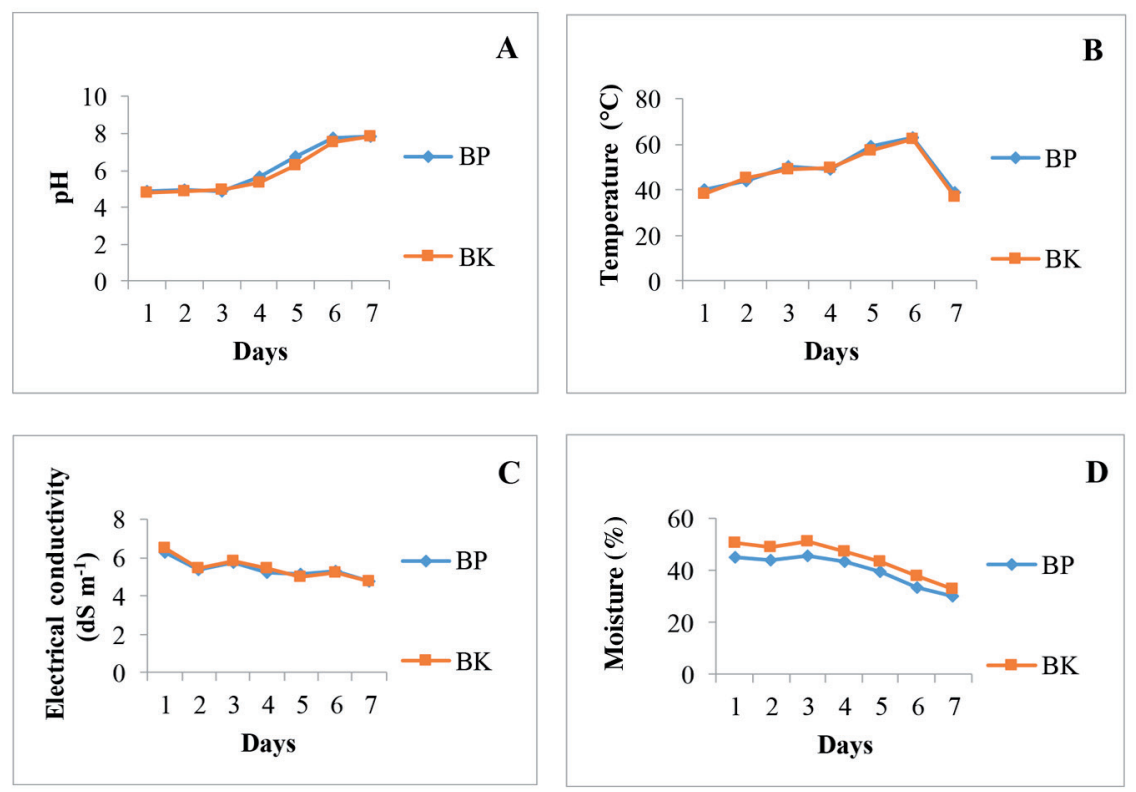

BP: Bokashi with 9\% rock phosphate in the composting process; BK: bokashi without rock phosphate in the composting process. 
case of compost, this condition is associated with a product that has not been stabilized because high quality compost uses the low level or absence of ammoniacal $\mathrm{N}$ as indicators, and it is recommended a maximum of $0.4 \%$ in the final product (Kalamdhad and Kazmi, 2009). Salinity increases due to the release of soluble salts that occur through the decomposition activity (Prasad et al., 2013), which is unfinished by reducing pile height and subsequently decreasing microbial activity.

The treatments had a significant effect $(\mathrm{P} \leq 0.05)$ only on the final content of $\mathrm{OM}$, soluble $\mathrm{P}$, and soluble $\mathrm{Ca}$. Differences in the $\mathrm{OM}$ and organic $\mathrm{C}$ content could be caused by the dilution factor because content during the preparation of BK piles was 100 and $110 \mathrm{~kg}$ for $9 \% \mathrm{BP}$ piles.

The soluble $\mathrm{P}$ and $\mathrm{Ca}$ contents were higher in $\mathrm{BP}$, thus effectively improving the biofertilizer in terms of $\mathrm{P}$ and $\mathrm{Ca}$ nutrition. This is due to the mineral contribution rock phosphate provides (Table 2).

During the bokashi preparation process, $\mathrm{P}$ solubilization from rock phosphate could have been present by lowering $\mathrm{pH}$, releasing protons associated with ammonium assimilation, such as the production of organic acids from the metabolism of microorganisms (Yadav and Verma, 2012).

The same occurs with $\mathrm{Ca}$, which increases its solubility when the medium is acidified, and also the complexation of cations associated with insoluble phosphates by organic acids produced by microorganisms (Tallapragada, 2015).

\section{Effect of bokashi on the chlorophyll index}

Except the 10\% added rock phosphate bokashi treatment (BRE10), all treatments differed from the control (B0). Table 3 shows an increase in the chlorophyll content in treatments with a higher bokashi rate, and BRM30 is different from all the other treatments at the $10 \%$ bokashi rate and those at the $15 \%$ rate that did not add rock phosphate to the pot. This can be because the amount of rock phosphate added to the pots was greater than the amount incorporated into the bokashi piles during their preparation for its $\mathrm{v} / \mathrm{v}$ ratio, and density of $3.07 \mathrm{~g} \mathrm{~cm}^{-3}$ according to the Ecofos supplies, while the ratio was w/w during the preparation. Furthermore, Farias et al. (2015) reported that a fertilizer with rock phosphate applied directly to the soil increases the crop chlorophyll index compared with a control without fertilization and maintains levels similar to one with soluble P fertilization. Abbasi et al. (2015) claim that the high content of OM plays an important role in the solubility of $\mathrm{P}$ because it has the ability to form chelates. The $\mathrm{OM}$ and its microbial activity also produce acids that help solubilize rock phosphate during its decomposition stage, and the moderately acidic $\mathrm{pH}$ of the soil can favor the dissolution of rock phosphate (Alzoubi and Gaibore, 2012).

Soil with adequate amounts of OM, and the precise addition of N, P, and $\mathrm{K}$, is transformed into increased chlorophyll content (Lasmini et al., 2018; Contreras et al., 2019). Tuncay (2011) and Soltangheisi et al. (2013) indicate that increases in chlorophyll can be related to higher absorption of $\mathrm{N}$ and $\mathrm{P}$ given the larger fertilizer rates.

\section{Effect of bokashi on dry matter (DM) content}

All treatments, except 10\% bokashi without rock phosphate (BSR10), performed better than B0. The highest yield was obtained with $15 \%$ bokashi + rock phosphate in the preparation (BRE15), followed by $10 \%$ bokashi $+9 \%$ rock phosphate

Table 2. Physicochemical analysis of bokashi prepared with and without rock phosphate and reference values for compost.

\begin{tabular}{|c|c|c|c|}
\hline Evaluated parameter & $\begin{array}{l}\text { With rock } \\
\text { phosphate }\end{array}$ & $\begin{array}{l}\text { Without rock } \\
\text { phosphate }\end{array}$ & $\begin{array}{l}\text { Accepted values for } \\
\text { compost }\end{array}$ \\
\hline Organic matter, $\%$ & $30.23 \mathrm{a}$ & $36.33 b$ & $\geq 20$ \\
\hline Organic C, \% & $16.80 \mathrm{a}$ & $20.20 \mathrm{~b}$ & \\
\hline Total $\mathrm{N}, \%$ & $1.16 \mathrm{a}$ & $1.33 \mathrm{a}$ & $\geq 0.5$ \\
\hline Ammoniacal $\mathrm{N}\left(\mathrm{N}-\mathrm{NH}_{4}\right), \mathrm{mg} \mathrm{kg}^{-1}$ & $2498.10 \mathrm{a}$ & $2454.05 \mathrm{a}$ & $\leq 500$ \\
\hline Nitric $\mathrm{N}\left(\mathrm{N}-\mathrm{NO}_{3}\right), \mathrm{mg} \mathrm{kg}^{-1}$ & $0.20 \mathrm{a}$ & $0.23 \mathrm{a}$ & \\
\hline $\mathrm{C} / \mathrm{N}$ ratio & $14.48 \mathrm{a}$ & $15.25 \mathrm{a}$ & $\leq 30$ \\
\hline Ammonium/nitrate ratio & $11074.22 \mathrm{a}$ & $10669.78 \mathrm{a}$ & $\leq 3$ \\
\hline Soluble P, $\mathrm{mg} \mathrm{kg}^{-1}$ & $79.50 \mathrm{~b}$ & $67.50 \mathrm{a}$ & \\
\hline Soluble $\mathrm{K}, \mathrm{mg} \mathrm{kg}^{-1}$ & $7969.33 \mathrm{a}$ & $9066.33 \mathrm{a}$ & \\
\hline Soluble $\mathrm{Ca}, \mathrm{mg} \mathrm{kg}^{-1}$ & $357.00 \mathrm{~b}$ & $179.00 \mathrm{a}$ & \\
\hline $\mathrm{pH}$ & $7.82 \mathrm{a}$ & $7.58 \mathrm{a}$ & $5.5-8.5$ \\
\hline $\mathrm{CE}, \mathrm{dS} \mathrm{m}^{-1}$ & $4.66 \mathrm{a}$ & $4.85 \mathrm{a}$ & \\
\hline
\end{tabular}

Different letters in the same row indicate significant differences according to Student-Fischer's t-test $(\mathrm{P} \leq 0.05)$. 
Table 3. Effect of applying different treatments with bokashi on chlorophyll index, dry matter, foliar P, and remaining soil P.

\begin{tabular}{lcccc}
\hline Treatment & $\begin{array}{c}\text { Chlorophyll } \\
\text { index }\end{array}$ & Dry matter & Foliar P & $\begin{array}{c}\text { Remaining } \\
\text { soil P }\end{array}$ \\
\hline & & $\mathrm{g}$ & $\%$ & $\mathrm{mg} \mathrm{kg}^{-1}$ \\
B0 & $23.08 \mathrm{a}$ & $0.77 \mathrm{a}$ & $0.11 \mathrm{a}$ & $4.77 \mathrm{a}$ \\
BRE10 & $27.0 \mathrm{ab}$ & $3.88 \mathrm{bc}$ & $0.13 \mathrm{ab}$ & $8.79 \mathrm{~b}$ \\
BSR10 & $28.5 \mathrm{bc}$ & $2.18 \mathrm{ab}$ & $0.14 \mathrm{ab}$ & $8.72 \mathrm{~b}$ \\
BRM10 & $30.4 \mathrm{bcd}$ & $4.89 \mathrm{c}$ & $0.13 \mathrm{ab}$ & $9.39 \mathrm{bc}$ \\
BRE15 & $30.22 \mathrm{bcd}$ & $5.48 \mathrm{c}$ & $0.15 \mathrm{ab}$ & $11.0 \mathrm{~cd}$ \\
BSR15 & $30.2 \mathrm{bcd}$ & $3.72 \mathrm{bc}$ & $0.13 \mathrm{ab}$ & $11.37 \mathrm{~d}$ \\
BRM15 & $32.4 \mathrm{cde}$ & $4.07 \mathrm{bc}$ & $0.14 \mathrm{ab}$ & $10.43 \mathrm{~cd}$ \\
BRE30 & $34.5 \mathrm{de}$ & $3.5 \mathrm{bc}$ & $0.16 \mathrm{~b}$ & $23.31 \mathrm{e}$ \\
BSR30 & $34.56 \mathrm{de}$ & $3.34 \mathrm{bc}$ & $0.17 \mathrm{~b}$ & $21.71 \mathrm{e}$ \\
BRM30 & $35.85 \mathrm{e}$ & $3.49 \mathrm{bc}$ & $0.16 \mathrm{~b}$ & $22.17 \mathrm{e}$ \\
\hline
\end{tabular}

Different letters in the same column indicate significant differences according to Tukey's test $(\mathrm{P} \leq 0.05)$.

B0: Control treatment; BRE10: 10\% bokashi with rock phosphate in the composting process; BSR 10: 10\% bokashi without rock phosphate in the composting process; BRM10: 10\% bokashi without rock phosphate in the composting process $+9 \%$ rock phosphate added directly to the pot; BRE15: $15 \%$ bokashi with rock phosphate in the composting process; BSR15: 15\% bokashi without rock phosphate in the composting process; BRM15: 15\% bokashi without rock phosphate in the composting process $+9 \%$ rock phosphate added directly to the pot; BRE30: $30 \%$ bokashi with rock phosphate in the composting process; BSR30: 30\% bokashi without rock phosphate in the composting process; BRM30: $30 \%$ bokashi without rock phosphate in the composting process $+9 \%$ rock phosphate added directly to the pot.

in the pot (BRM10) (Table 3). The DM production increased when biofertilizer was added; this remained constant when the bokashi rate increased. These results concur with those reported by Boudet et al. (2015), who obtained a constant performance with bell pepper when increasing the bokashi rate.

The increase in yields after fertilization can be attributed to higher amounts of soil $\mathrm{P}$ increasing biomass production (Sarker et al., 2014). Muñoz et al. (2012) demonstrated that yields can decrease or stagnate when the biofertilizer rate is increased compared with the highest values obtained with an optimal rate. This is because the high microorganism load provided at a high rate competes with the plant for the existing mineral $\mathrm{N}$ for its development, leaving only organic $\mathrm{N}$, which slowly mineralizes to become available for the crop.

\section{Effect of bokashi on foliar P content}

Treatments with the $30 \%$ bokashi rate, BRE30, BSR30, and BRM30, exhibited the highest foliar P content, which was different compared to $\mathrm{B} 0$ (Table 3 ).

According to Havlin et al. (2013), most plants have a leaf P concentration in DM varying between $0.1 \%$ and $0.4 \%$. Foliar $\mathrm{P}$ content is close to the minimal range because the assay was carried out in the fall-winter season. According to Yan et al. (2012), air temperature in winter can be high, while soil temperature can vary very slightly and remain around $10{ }^{\circ} \mathrm{C}$; this means that nutrient absorption, especially $\mathrm{P}$, can be inhibited because of low temperatures in the root zone.

\section{Effect of bokashi on $P$ remaining in the soil}

There is a marked increase in the P levels remaining in the soil as the applied bokashi rate increases. Every treatment with fertilization had a higher concentration of soil available $\mathrm{P}$ after harvest than the control (Table 3).

There were no apparent differences between the amount of P in BP in the preparation and BK, although the former showed significant differences in its level of available P compared with BK. This could be because the $9 \%$ rock phosphate rate used in the preparation of the improved bokashi was not sufficient to increase $\mathrm{P}$ availability in the soil mixture with bokashi.

Treatments at 30\% bokashi, BRE30, BSR30, and BRM30, behaved in a similar manner and, as expected, exhibited the highest levels of soil available $\mathrm{P}$ after harvest. According to Saldaña et al. (2014), bokashi has a high index of active mineralization, and they also report that the use of organic fertilizers maintains higher levels of soil available $\mathrm{P}$ than in a control treatment. 


\section{CONCLUSIONS}

The addition of rock phosphate in the preparation process of bokashi had a positive effect by increasing the $\mathrm{P}$ and $\mathrm{Ca}$ content of the biofertilizer.

The application of bokashi increased the chlorophyll index in parsley leaves, and the dry matter weight increased in all the treatments with the bokashi application, except the $10 \%$ bokashi treatment without rock phosphate (BSR10). At the $30 \%$ rates, the three types of bokashi increased the foliar P levels of the parsley plants and soil P content.

Although the rock phosphate enhanced biofertilizer showed differences in $\mathrm{P}$ availability compared with the one without rock phosphate, the analyzed parameters, such as chlorophyll index, dry matter, foliar P concentration, and remaining soil available $\mathrm{P}$ in the pots did not vary according to the type of bokashi used, but only effectively responded to the different applied rates.

\section{ACKNOWLEDGEMENTS}

The authors would like to thank the Instituto de Investigaciones Agropecuarias (INIA) for its financial support.

\section{REFERENCES}

Abbasi, M.K., Musa, N., and Manzoor, M. 2015. Mineralization of soluble P fertilizers and insoluble rock phosphate in response to phosphate-solubilizing bacteria and poultry manure and their effect on the growth and P utilization efficiency of chilli (Capsicum annuит L.) Biogeosciences 12:4607-4619. doi:105194/bg-12-4607-2015.

Alzoubi, M., and Gaibore, M. 2012. The effect of phosphate solubilizing bacteria and organic fertilization on availability of Syrian rock phosphate and increase of triple superphosphate efficiency. World Journal of Agricultural Sciences 8(5):473-478. http://doi:10.5829/idosi.wjas.2012.8.5.1668.

Boudet, A., Chinchilla, V., Boicet, T., and González, G. 2015. Effects of different doses of organic fertilizer type bokashi in morphological and productive indicators of pepper crop (Capsicum annuum L.) var. California Wonder. Centro Agrícola 42:5-9.

Chennaoui, M., Salama, Y., Aouinty, B., Mountadar, M., and Assobhei, O. 2018. Evolution of bacterial and fungal flora during in-vessel composting of organic household waste under air pressure. Journal of Materials and Environmental Sciences 9(2):680-688. http//doi.org/10.26872/jmes.2018.9.2.75.

Christel, D. 2017. The use of bokashi as a soil fertility amendment in organic spinach cultivation. 151 p. MSc thesis. University of Vermont, Graduate College, Burlington, Vermont, USA.

Contreras, C., Schwab, W., Mayershofer, M., Morales, I., Gonzalez-Agüero, M., and Defilippi, B.G. 2019. Study of physiological and quality parameters during development and ripening of pepino (Solanum muricatum Aiton) fruit. Chilean Journal of Agricultural Research 79:385-395. doi:10.4067/S0718-58392019000300385.

Delfim, J., Schoebitz, M., Paulino, L., Hirzel, J., and Zagal, E. 2018. Phosphorus availability in wheat, in volcanic soils inoculated with phosphate-solubilizing Bacillus thuringiensis. Sustainability 10:144. doi:10.3390/su10010144.

Dou, L., Komatsuzaki, M., and Nakagawa, M. 2012. Effects of biochar, mokusakueki and bokashi application on soil nutrients, yields, and qualities of sweet potato. International Research Journal of Agricultural Science and Soil Science 2(8):318-327.

Farias, L., Bonfim-Silva, E., Guimaraes, S., de Souza, A., da Silva, T., and Schlichting, A. 2015. Concentration of nutrients and chlorophyll index in pigeon pea fertilized with rock phosphate and limiting in Cerrado Oxisol. African Journal of Agricultural Research 10:1743-1750.

Ferreira, J., Hernandes, I., Brito, O., Cardoso, M., and Dias-Arieira, C. 2016. Dosages of bokashi in the control of Meloidogyne javanica in lettuce, in greenhouse. Horticultura Brasileira 35:22-229. http://dx.doi.org/10-1590/S0102-053620170211.

Havlin, J., Tisdale, S., Nelson, W., and Beaton, J. 2013. Soil fertility and fertilizers. An introduction to nutrient management. $8^{\text {th }}$ ed. Prentice Hall, Upper Saddle River, New Jersey, USA.

INN. 2015. Norma Chilena Oficial Nch 2880. Of2004. Compost - Clasificación y requisitos. Instituto Nacional de Normalización (INN), Santiago, Chile.

Kalamdhad, A., and Kazmi, A. 2009. Rotary drum composting of different organic waste mixtures. Waste Management and Research 27:129-137. doi:10.1177/0734242X08091865.

Karazija, T., Cosic, T., Lazarevic, B., Horvat, T., Petek, M., Palcic, I., et al. 2015. Effect of organic fertilizers on soil chemical properties on vineyard calcareous soil. Agriculturae Conspectus Scientificus 80(2):79-84.

Karimuna, L., Rahni, N.M., and Boer, D. 2016. The use of bokashi to enhance agricultural productivity of marginal soils in Southeast Sulawesi, Indonesia. Journal of Tropical Crop Science 3:1-6. 
Lasmini, S., Nasir, B., Hayati, N., and Edy, N. 2018. Improvement of soil quality using bokashi composting and NPK fertilizer to increase shallot yield on dry land. Australian Journal of Crop Science 12(11):1743-1749. doi:10.21475/ajcs.18.12.11.p1435.

Maluf, H., Silva, C., Morais, E., and Duarte, L. 2018. Is composting a route to solubilize low-grade phosphate rocks and improve MAP-based composts? Revista Brasileira de Ciência do Solo 42:e0170079. http://doi.org/10.1590/18069657rbcs20170079.

Muñoz, J., Velásquez, M., y Macias, H. 2012. Uso de composta en la producción de chile jalapeño (Capsicum annuum L.) bajo condiciones de invernadero. Agricultura Orgánica. Revista Agrofaz 12(3):9-15.

Patel, D., Das, A., Kumar, M., Munda, G.C., Ngachan, S.V., Ramkrushna, G.I., et al. 2015. Continuous application of organic amendments enhances soil health, produce quality system productivity of vegetable-based cropping systems in Subtropical eastern Himalayas. Experimental Agriculture 51:85-106.

Prasad, R., Singh, J., and Kalamdhad, A. 2013. Assessment of nutrients and stability parameters during composting of water hyacinth with cattle manure and sawdust. Research Journal of Chemical Sciences 3(4):70-77.

Roy, E., Richards, P., Martinelli, L., Coletta, L., Lins, S., Vazquez, F., et al. 2016. The phosphorus cost of agricultural intensification in the tropics. Nature Plants 2:16043. http://doi.org/10.1038/nplants.2016.43.

Sadzawka, A., Carrasco, M., Grez, R., Mora, M., Flores, H., y Neaman, A. 2006. Métodos de análisis recomendados para los suelos de Chile. Instituto de Investigaciones Agropecuarias (INIA), Santiago, Chile.

SAG. 2013. Agricultura orgánica nacional. Bases técnicas y situación actual. Servicio Agrícola y Ganadero (SAG), Santiago, Chile.

Saldaña, M., Gómez, R., Rivera, M., Álvarez, J., Pat, J., and Ortiz, C. 2014. The influence of organic fertilizers on the chemical properties of soil and the production of Alpinia purpurata. Ciencia e Investigación Agraria 41(2):215-224. doi:10.4067/S0718-16202014000200008.

Sarker, A., Kashem, A., and Towhid, K. 2014. Phosphorus availability, uptake and dry matter yield of Indian spinach (Basella alba L.) to lime and phosphorus fertilization in an acidic soil. Open Journal of Soil Science 4:42-46.

Schenkel, G., y Baherle, P. 1971. Exploración de deficiencias nutritivas con suelos en macetas. II. Método usado. Agricultura Técnica 31:9-24.

Sharma, D., Varma, V., Yadav, K., and Kalamdhad, S. 2017. Evolution of chemical and biological characterization during agitated pile composting of flower waste. International Journal of Recycling of Organic Waste in Agriculture 6(1):89-98. doi:10.1007/s40093-017-0155-9.

Soltangheisi, A., Fauziah, C., Musa, H., Zakikhani, H., and Abdul, Z. 2013. Phosphorus and zinc uptake and their interaction effect on dry matter and chlorophyll content of sweet corn (Zea mays var. saccharata). Journal of Agronomy 12(4):187-192.

Tallapragada, P. 2015. Solubilization of different inorganic phosphates by Aspergillus niger and Penicilium oxalicum. Advances in Bioresearch 6:113-119.

Tuncay, O. 2011. Relationships between nitrate, chlorophyll and chromaticity values in rocket salad and parsley. African Journal of Biotechnology 10:17152-17159.

Wang, Z., Gao, M., Wang, Z., She, Z., Hu, B., Wang, Y., et al. 2013. Comparison of physicochemical parameters during the forced aeration composting of sewage sludge and maize straw at different initial $\mathrm{C} / \mathrm{N}$ ratios. Journal of the Air \& Waste Management Association 63(10):1130-1136. doi:10.1080/10962247.2013.800616.

Yadav, B., and Verma,A. 2012. Phosphate solubilization and mobilization in soil through microorganisms under arid ecosystems. In Mahamane, A. (ed.) The functioning of ecosystems. InTech, Rijeka, Croatia.

Yan, Q., Duan, Z., Mao, J., Li, X., and Dong, F. 2012. Effects of root-zone temperature and N, P, and K supplies on nutrient uptake of cucumber (Cucumis sativus L.) seedlings in hydroponics. Soil Science and Plant Nutrition 58(6):707-717. doi:10.1080/00380768.2012.733925

Zaha, C., Dumitrescu, L., and Manciulea, I. 2013. Correlations between composting conditions and characteristics of compost as biofertilizer. Bulletin of the Transilvania University of Brasov Series I: Engineering Sciences 6(55):51-58.

Zaman, M., Ahmed M., and Gogoi, P. 2016. Effect of bokashi on plant growth, yield and essential oil quantity and quality in Patchouli (Pogostemon cablin Benth.) Biosciences Biotechnology Research Asia 7:383-387. 